\title{
Muscle recruitment and co-contraction when walking in young women with chronic lumbar pain
}

\author{
Recrutamento e cocontração muscular durante a marcha \\ em mulheres jovens com dor lombar crônica
}

Reclutamiento y co-contracción muscular durante la
marcha en mujeres jóvenes con dolor lombar crónica

Beatriz Mendes Tozim ([a], Guilherme Thomaz de Aquino Nava ([)[b], Ana Elisa Zuliani Stroppa Marques $\mathbb{[}^{[a]}$, Nise Ribeiro Marques $\circledast^{[b]}$, Mary Hellen Morcelli $₫[c]$, Marcelo Tavella Navega (i] [a, c]*

[a] Universidade Estadual Paulista (Unesp), Marília, SP, Brazil

[b] Universidade Sagrado Coração (USC), Bauru, SP, Brazil

[c] Universidade Estadual Paulista (Unesp), Rio Claro, SP, Brazil

\section{Abstract}

Introduction: The lumbar pain is the main musculoskeletal complaint reported by the active population, and it prevents daily activities such as walking. Objective: To assess muscle recruitment and the co-contraction of the trunk muscles during different walking speed in individuals with and without chronic lumbar pain. Method: Thirty-four sedentary young women attended the study, in which 18 belonged to the lumbar pain team (LPT) and 16 to the team without lumbar pain (WLP). We assessed the electromyography activity of the internal oblique (IO) local muscle and lumbar multifidus (MUL), and global external oblique (EO), abdominal rectus (AR) and lumbar iliocostalis (LIC), during walking. The electromyography analysis was performed from the average of the

\footnotetext{
* BMT: PhD, e-mail: beatriztozim@yahoo.com.br GTAN: Doctoral student, e-mail: gtnava@gmail.com AEZSM: PhD, e-mail: anastropa@hotmail.com NRM: PhD, e-mail:nisermarques@yahoo.com.br MHM: PhD, e-mail: morcellimh@gmail.com MTN: PhD, e-mail: navega@marilia.unesp.br
} 
linear envelope value, normalized by the peak of muscle activation. The muscle co-contraction (IO/MUL, EO/LIC, AR/LIC, IO/EO, and the abdominal/paravertebral muscle groups) was calculated with the Falconer and Winter formula. The Shapiro-Wilk test, Multivariate Analysis, mixed Variance Analyses with Bonferroni post-hoc, and Pearson $(\mathrm{p}<0.05)$ correlation coefficient were made by the statistical analysis. Results: In the WLP we could notice that the higher the speed, the higher the MUL activation. The co-contraction data demonstrated that IO/ MUL muscles activate 20\% more in the LPT, during the preferred speed; however, in the WLP, the results showed that the higher the walking speed, the higher the EO/LIC (21.8\%) and IO/MUL (17.8\%) muscles activation. Conclusion: The recruitment of local muscles doesn't differ among the evaluated groups and conditions; however, in WLP, the higher the MUL muscle action, the higher the walking speed.

Keywords: Lumbar Pain. Electromyography. Walking. Applied Kinesiology.

\section{Resumo}

Introdução: A dor lombar (DL) é a principal queixa musculoesquelética relatada na população ativa e incapacita atividades do cotidiano, como a marcha. Objetivo: Avaliar o recrutamento e co-contração dos músculos do tronco durante diferentes velocidades de marcha em indivíduos com e sem DL crônica. Método: Participaram 34 mulheres jovens, sedentárias, 18 compuseram o grupo DL (GDL) e 16 o grupo sem DL (GC). Foi avaliada a atividade eletromiográfica dos músculos locais oblíquo interno (OI) e multífido lombar (MUL), e globais oblíquo externo (OE), reto abdominal (RA) e iliocostal lombar (ICL), durante a marcha. A análise eletromiográfica foi realizada a partir da média do valor de envelope linear, normalizada pelo pico de ativação muscular. A co-contração muscular (OI/MUL, OE/ICL, RA/ICL, OI/OE e os grupos musculares abdominais/paravertebrais) foi calculada com a fórmula de Falconer e Winter. A análise estatística foi feita por meio do teste Shapiro-Wilk, Análise Multivariada, Análise de Variância mista com pos-hoc bonferroni e coeficiente de correlação de Pearson ( $p<0,05)$. Resultados: No GC podemos perceber que, quanto maior a velocidade, maior a ativação do MUL. Os dados de co-contração demonstraram que os músculos OI/MUL ativam 20\% a mais no GDL, durante a velocidade de preferência, no GC, os resultados mostram que quanto maior a velocidade de marcha, maior a ativação dos músculos OE/ICL $(21,8 \%)$ e OI/MUL (17,8\%). Conclusão: O recrutamento dos músculos não difere entre os grupos e condições, contudo foi observado no GC que quanto maior a ação do músculo MUL maior é a velocidade de marcha.

Palavras-chave: Dor Lombar. Eletromiografia. Marcha. Cinesiología Aplicada.

\section{Resumen}

Introducción: El dolor lumbar (DL) es la principal queja musculoesquelética relatada e incapacita actividades de lo cotidiano, como la marcha. Objetivo: Evaluar el reclutamiento y la co-contracción músculos del tronco durante diferentes velocidades de marcha en individuos con y $\sin$ DL. Método: Participaron 34 mujeres jóvenes, sedentarias, 18 compusieron grupo DL (GDL) y 16 grupo sin DL (GC). Se evaluó la actividad electromiográfica de los músculos oblicuo interno (OI) y externos (OE), multífido lumbar (MUL), recto abdominal (RA) e iliocostal lumbar (ICL) durante la marcha. El análisis electromiográfico fue realizado a partir del promedio del valor de sobre lineal, normalizado por el pico de activación muscular. La cocontracción muscular (OI/MUL, OE/ICL, RA/ICL, OI/OE y grupos de músculos abdominales/paravertebrales) se calculó utilizando la fórmula Falconer y Winter. El análisis estadístico fue realizado por Shapiro-Wilk, Análisis Multivariado, Análisis de Variedad mixta con pos-hoc bonferroni y coeficiente de correlación de Pearson ( $p<0,05)$. Resultados: En el GC podemos percibir que, cuanto mayor es la velocidad, mayor es la activación del MUL. Los datos de co-contracción demostraron que los músculos OI/MUL activan un 20\% más en el GDL, durante la velocidad de preferencia, sin embargo, en el GC, los resultados muestran que cuanto mayor la velocidad de marcha, mayor la activación de los músculos OE / ICL (21,8\%) y OI/MUL (17,8\%). Conclusión: El reclutamiento de los músculos no difiere entre los grupos y condiciones, contenido observado en el GC que cuanto mayor es la acción del músculo MUL mayor es la velocidad de marcha.

Palabras clave: Dolor de la Región Lumbar. Electromiografia. Marcha. Quinesiología Aplicada. 


\section{Introduction}

The lumbar pain [LP] is the main physical complaint reported by the active population [1] and mainly in voluntary activities, in which $80 \%$ of them evolve with symptom remission, while $20 \%$ become chronic [2]. The high incidence of LP in the population results in an increase in health expenses and longer work leave time [3]. To perform several different daily activities (DA), we need some systems that maintain spine stability and consequently keep it healthy [4].

The spine stabilization is performed through the active, passive, and neural systems that simultaneously act and control movements [4]. The muscles belong to the active system and stabilize the vertebral segments [5]. They can be split into local and global stabilizers, according to their functions $[4,5]$. The local stabilizer muscles are unisegmental and promote intervertebral control; the internal oblique (IO) and the lumbar multifidus (MUL) muscles belong to this system $[5,6]$. The global stabilizer muscles present moving characteristics, with torque production and are compound by external oblique (EO), abdominal rectus (AR), and lumbar iliocostal (LIC) muscles [4-6].

During dynamic movements, stability is challenged all the time, and the muscle cocontraction is one of the mechanisms that the central nervous system (CNS) has to stabilize a certain segment [6-9]. Walking is a dynamic task with high frequency during the day, and as far as it is known, in the presence of chronic lumbar pain (CLP) the individuals present lower amplitude of the articular movement, rigidity, shorter step length, higher step width $[10,11]$ and shorter walking speed. These are predictors of the individual physical conditions, once the preferred speed refers to the characteristics of the daily life rhythm, while the fast walking refers to the adaptation capacity to the efforts [11], thus culminating in functional limitation, inability, and pain [12].

Therefore, this work's objective was to assess the recruitment and co-contraction of the trunk muscles during different walking speeds, in individuals with and without CLP. We hypothesize that the participants with CLP will have lower walking speed, higher muscle recruitment, and higher trunk muscle co-contraction when compared to the control team.

\section{Methods}

Transversal, quantitative study approved by the Research Ethics Committee of the Faculdade de Filosofia e Ciências, UNESP Marília campus (no. 0863/2013). We informed all participants about the research, and they signed the Informed Consent Form. The collection was performed at the campus of Faculdade de Filosofia e Ciências, UNESP Marília campus.

\section{Participants}

Thirty-four sedentary women attended the survey, aging from 18 to 27 years old; from which 18 composed the chronic lumbar pain team (LPT) and 16 composed the control team (CT), see Table 1.

Table 1 - Sample characterization. Data presented in average and standard deviation (average \pm SD)

\begin{tabular}{lccc}
\hline & LPT & CT & S \\
\hline Age (years old) & $21.56 \pm 3.17$ & $21.00 \pm 1.97$ & 0.549 \\
Height (meters) & $1.66 \pm 0.09$ & $1.65 \pm 0.07$ & 0.522 \\
Body mass (Kg) & $57.82 \pm 8.35$ & $56.02 \pm 7.84$ & 0.728 \\
BMl (Kg/m2) & $21.02 \pm 3.17$ & $20.54 \pm 2.61$ & 0.633 \\
Pain on the test day (cm) & $1.28 \pm 1.75$ & 0 & - \\
Daily pain (cm) & $3.06 \pm 2.24$ & 0 & - \\
\hline
\end{tabular}

Note: LPT: chronic lumbar team; CT: control team; Kg: kilograms; m2: square meters; $\mathrm{cm}=$ centimeters; BMl: body mass index; VAS: visual analogue scale.

The criteria for LPT eligibility were to be female, sedentary for at least six months, with at least two idiopathic episodes of lumbar region pain in the last three months [13]. The inclusion criteria were the same for WLP; however, the participants should not have presented episodes of lumbar pain in the last three months. The non-eligibility criteria were treatment with anti-inflammatory or analgesic in the last 72 hours; with nervous compression signal [12], ankylosing spondylitis, rheumatoid arthritis, tumor presence in the spine, vertebral fracture, equine tail syndrome [14], BMI higher than $29.99 \mathrm{~kg} / \mathrm{m}^{2}$ [15] and not to be able to perform $120^{\circ}$ of trunk flexion.

A pilot study with four volunteers in each team performed the sample calculation. The used variable was of co-contraction of IO/MUL muscles for the condition 1 of walking, with the power of 0.80 , error probability $\alpha$ of 0.05 , effect size of 0.875 , estimating the need of thirty-four volunteers as a whole. 


\section{Procedures}

Data collection consisted of the evaluation of the pain intensity at the lumbar region, and the electromyography during walking. The Visual Analogue Scale (VAS) measured the pain intensity; it was verified with a ruler from "without pain/ discomfort" until "worse pain/discomfort" [16]. We requested the participants to mark the pain intensity felt at the collection moment and the daily pain intensity to quantify the value obtained in the test [16]. The walking was evaluated during the ten first cycles in two conditions. The tests were randomly performed to avoid the execution order interfered with the results [7], break of two minutes between the conditions and familiarization with the preferred speed for five minutes [7]. We guided the volunteers not to use the support base of the treadmill handles and to remain barefoot during the collection [15].

To determine the preferred speed used at the treadmill, a speed evaluation on the floor was initially used, where the participants walked on a 20-meter track, and the time used to walk the central 10 meters was measured, deducing the initial and final 5 meters [7]. The test was performed three times, and the average value was defined as the floor walking preferred speed [7]. It was used 50\% of the preferred speed on the floor to start the test on the treadmill; this speed was gradually increased until the participant refers that it was "faster than usual" [17]. After reaching this mark, the speed was gradually decreased until the participants referred that it was "slower than the usual one" [17]. The test was performed three times and used the average of 6 values to determine the preferred speed on treadmill $[14,17]$. The second condition evaluated was during the maximum speed on the treadmill. To determine this value, we guided the volunteers to walk at the fastest speed possible without running [18].

\section{Electromyography}

We collected the electromyographic data during the walking on an INBRAMED ${ }^{\circledR}$ ergometric treadmill. Data about the dominance of lower members were collected to define the side the electrodes should be positioned for the electromyographic evaluation. The dominance was evaluated by tests of going up and down a step, kicking a ball at the target, and by the former displacement test [19]. We used an acquisition module of biological signals Model MyosystemBr1_ P84 (Data Hominis ${ }^{\circledR}$ ) of 8 channels, software MyosistemBr $1{ }^{\circledR}$ to capture the electromyographic signals. This module was used for the collection, real-time visualization, data storing and processing, calibrated with sample frequency of $2000 \mathrm{~Hz}$, total gain of 2000 times (20 times in the sensor and 100 times on the equipment), and rejection index of common way of $92 \mathrm{~dB}$ to $60 \mathrm{~Hz}$.

The skin was previously prepared by performing a trichotomy with a razor blade on the region where the electrodes were placed; the cleanliness of the area was made with alcohol and the abrasion with gauze to decrease the impedance on the region [20]. We used electrodes of the active surface of $\mathrm{Ag} / \mathrm{AgCl}$ (Data Hominis ${ }^{\circledR}$ ) formed by two rectangular bars $(10 \times 1 \mathrm{~mm})$ and distant $10 \mathrm{~mm}$ from each other, fixed with adhesive tape on the skin. A reference electrode was positioned over the ulnar styloid process [4], and the surface electrodes were positioned on the dominant side [19].

The participants were in dorsal decubitus for the location and positioning of the electrodes:

- I0: $2 \mathrm{~cm}$ medial and inferior to the anteroposterior iliac spine (EIAS) [21].

- AR: $1 / 2$ the distance between the xiphoid process and the umbilical scar, $3 \mathrm{~cm}$ lateral [22].

- EO: $1 / 2$ the distance between the EIAS and the inferior region of the rib cage [23].

The participants were in ventral decubitus for the location and positioning of the electrodes:

- MUL: Positioned on the line that links the posterior superior iliac spine and the space between L1 and L2 at the level of L5 [20].

- LIC: $6 \mathrm{~cm}$ laterally to the space between the spiny processes of L2-L3 [24].

\section{Electromyographic analysis}

The electromyographic analysis occurred during the walking, along with the ten consecutive stepping cycles, determined from the visual assessment made by the same assessor, of 10 calcaneus touches of the lower limb on the ergometric treadmill. From specific routines on the software Matlab $^{\circledR}$, the 
electromyographic signal was filtered through the $4^{\text {th }}$ order high-pass filter Butterworth with cut frequency of $20 \mathrm{~Hz}$ and a $4^{\text {th }}$ order low-pass filter Butterworth with cut frequency of $500 \mathrm{~Hz}$. Afterward, the signal was rectified by full-wave and softened with a $4^{\text {th }}$ order low-pass filter Butterworth with a cut frequency of $6 \mathrm{~Hz}$ to form the linear envelope. The electromyographic data of the muscular recruitment are in activation average of the linear envelope of 10 stepping cycles and normalized by the activation peak during the walking on treadmill with maximum speed to determine the muscular cocontraction from the percentage calculation of the co-contraction according to the formula of Falconer and Winter [25]:

$$
\% \text { con }- \text { con }=2 \times \frac{\text { Mantag }}{\text { MAgon + Mantag }} \times 100 \%
$$

$\mathrm{M}$ agon and $\mathrm{M}$ antag represent the moments of the strength of the agonists and antagonists respectively. The co-contraction was performed for the muscles IO/ MUL, EO/LIC, AR/LIC, IO/EO and for the abdominal/ paravertebral muscle groups (ABD/PARA). To determine the ABD/PARA co-contraction, from the IO, EO, and AR linear envelope, we created a new linear envelope that represents the activation average of the linear envelope referring to the abdominal muscles. For the paravertebral muscles, we performed the same procedure, creating a new linear envelope that represented the activation average of the linear envelope of the MUL and LIC muscles.

\section{Statistical analysis}

The software SPSS ${ }^{\circledR}$ analyzed the obtained data. Shapiro-Wilk test verified the normality of the data and we adopted the multivariate analysis, mixed analysis of variance considering the factors team and condition with post-hoc Bonferroni and Person correlation coefficient, considering significant when $\mathrm{p}<0.05$.

\section{Results}

Table 2 shows the walking speed values of both teams. With the main effect for speed $\mathrm{p}<0.001$ and $\mathrm{F}=175.092$, for the team $\mathrm{p}=0.270$ and $\mathrm{F}=1.258$, and for interaction Team X Condition $\mathrm{p}=0.237$ and $\mathrm{F}=1.509$, i.e., there is no significant difference at the walking speed between individuals with or without lumbar pain.

Table 2 - Walking speeds. Data presented in average and standard deviation (average \pm SD)

\begin{tabular}{lcc}
\hline Speed $(\mathrm{Km} / \mathrm{h})$ & LPT & CT (WLP) \\
\hline Preference on the floor & $4.26 \pm 0.54$ & $4.45 \pm 0.56$ \\
Preference on ergometric treadmill & $4.17 \pm 0.40$ & $4.20 \pm 0.41$ \\
Maximum of walking a, b & $5.60 \pm 0.62$ & $5.87 \pm 0.46$
\end{tabular}

Note: Km/h: kilometers per hour; LPT: Lumbar Pain Team; CT (WLP): Control Team. a Presents significant difference when compared with the floor preferred speed, not considering the team $(p<0.001)$; b Presents a significant difference when compared with the ergometric treadmill preferred speed, not considering the team, $(p<0.001)$.

Table 3 shows the values regarding the average muscular activation of the muscles EO, IO, MUL, AR, and LIC at the comparison between the teams and between the walking conditions. The main effect was for condition $\mathrm{p}<0.001$ and $\mathrm{F}=46.801$, for the team $\mathrm{p}=0.481$ and $\mathrm{F}=0.922$ and the interaction Team $\mathrm{X}$ Condition $\mathrm{p}=0.812$ and $\mathrm{F}=0.446$. The results demonstrated that by increasing the treadmill speed there was an increase in all the muscle recruitment when compared to condition 1 and condition 2 in each team; however, there was no difference between LPT and CT (WLP).

Table 3 - Recruitment of the trunk muscles. Data presented in average and standard deviation (average \pm SD)

\begin{tabular}{|c|c|c|c|c|c|c|c|c|}
\hline \multirow[b]{3}{*}{ EO } & \multicolumn{4}{|c|}{ LPT } & \multicolumn{4}{|c|}{ CT } \\
\hline & \multicolumn{2}{|c|}{ Condition 1} & \multicolumn{2}{|c|}{ Condition 2} & \multicolumn{2}{|c|}{ Condition 1} & \multicolumn{2}{|c|}{ Condition 2} \\
\hline & 0.259 & \pm 0.061 & 0.351 & $\pm 0.059 *$ & 0.228 & \pm 0.097 & 0.302 & \pm 0.096 * \\
\hline 10 & 0.268 & \pm 0.084 & 0.328 & $\pm 0.081^{*}$ & 0.269 & \pm 0.142 & 0.325 & \pm 0.091 * \\
\hline MUL & 0.138 & \pm 0.079 & 0.222 & $\pm 0.076^{\star}$ & 0.153 & \pm 0.065 & 0.217 & $\pm 0.064^{\star}$ \\
\hline$A R$ & 0.221 & \pm 0.125 & 0.307 & $\pm 0.119 *$ & 0.194 & \pm 0.105 & 0.283 & $\pm 0.134^{*}$ \\
\hline LIC & 0.141 & \pm 0.061 & 0.221 & $\pm 0.062^{*}$ & 0.156 & \pm 0.071 & 0.237 & $\pm 0.067^{*}$ \\
\hline
\end{tabular}

Note: E0: External oblique muscle; IO: Internal oblique muscle; MUL: Lumbar multifidus muscle; AR: Abdominal rectus muscle; LIC: Lumbar iliocostal muscle; LPT: Lumbar pain team; CT: control team. *Presented significant difference in comparison with the condition $(p<0.001)$. 
The recruitment results were correlated with the pain level obtained by EVA on the test day and daily on LPT and we observed moderate negative correlation among condition 2, maximum walking speed, EO muscle, and daily pain, which indicates that the higher the EO muscle activation during maximum walking speed, the lower the pain level $\left(r=\_0.570, p=0.014\right)$. On performing the correlation between the walking speed and the muscular recruitment, there was a significant difference between maximum walking speed and the MUL muscle recruitment at condition 2 for CT, which suggests that the higher the maximum speed, the higher the MUL muscle activation ( $r=0.540, p=0.031$ ).
Table 4 shows the values regarding the cocontraction of the local and global muscles with the main effect for the condition $\mathrm{p}<0.001$ and $\mathrm{F}=12.505$, for the team $\mathrm{p}=0.273$ and $\mathrm{F}=1.349$ and interaction Team X Condition $\mathrm{p}=0.018$ and $F=3.290$. At the interaction between Team $X$ Condition, the LPT at condition 1 presented cocontraction of IO/MUL $20 \%$ higher ( $\mathrm{p}=0.028$ ). Also, CT presented an increase of $21.8 \%$ at the contraction of the muscles EO/LIC $(\mathrm{p}<0.001)$ on comparing conditions 1 and 2 . The same also occurs for the muscles IO/MUL ( $\mathrm{p}<0.001)$, with an increase of $17.8 \%$.

Table 4 - Results of the co-contraction data. They were presented on average and standard deviation (average \pm SD)

\begin{tabular}{ccccccc}
\hline & \multicolumn{2}{c}{ LPT } & \multicolumn{3}{c}{ CT } \\
\hline & Condition 1 & Condition 2 & $\mathbf{( \% )}$ & Condition 1 & Condition 2 & (\%) \\
\hline IO/MUL & $61.54 \pm 15.14 \mathrm{a}$ & $64.17 \pm 14.41$ & 4 & $49.37 \pm 15.69$ & $60.11 \pm 16.40^{\mathrm{b}}$ & 17.8 \\
EO/LIC & $61.59 \pm 17.23$ & $64.52 \pm 18.78$ & 4.5 & $54.47 \pm 12.68$ & $69.72 \pm 17.88^{\mathrm{b}}$ & 21.8 \\
AR/LIC & $48.93 \pm 12.20$ & $58.68 \pm 15.62$ & 16.6 & $56.15 \pm 10.64$ & $63.74 \pm 17.14$ & 11.9 \\
IO/EO & $68.35 \pm 19.51$ & $73.98 \pm 19.26$ & 7.6 & $64.88 \pm 15.25$ & $74.31 \pm 18.35$ & 12.7 \\
ABD/PARA & $64.17 \pm 11.99$ & $69.16 \pm 14.61$ & 7.2 & $55.68 \pm 11.35$ & $63.83 \pm 11.18$ & 12.7 \\
\hline
\end{tabular}

Note: LPT: lumbar pain team; CT: Control team; (\%): Percentage; IO/MUL: Internal oblique muscles/multifidus lumbar; EO/LIC: External oblique muscle/lumbar iliocostal; AR/LIC: Abdominal rectus muscle/iliocostal lumbar; IO/EO: Internal oblique muscles/external oblique; ABD/PARA: Abdominal/paravertebral. a Presented significant difference between the teams, regarding the conditions $(p<0.05)$. ${ }^{\mathrm{b}}$ Presented significant difference in comparing the conditions between the teams $(p<0.05)$.

There was the statistical difference for the correlation data between the level of pain and trunk muscle co-contraction, and the same occurred on correlating the speed values (walking preference and maximum) with the standard co-contraction.

\section{Discussion}

Individuals with lumbar pain present stability loss, decreasing in their spine functionality [26]. The active trunk stability is guaranteed by the integration of three factors: load-bearing, mobility permission and lesions, and pain prevention [27], which are undermined in individuals with lumbar pain. The results showed that the preferred walking speed did not present significant differences between the teams, but this was not seen at the literature review that reports lower preferred speed and maximum walking in the elderly population [10]. This can occur due to the functional adaptation [11] that has as characteristic, for example, shorter step length and higher step width [1]. The findings corroborate the literature because the participants of this study are young; with this, the pain may not have interfered with the walking speed.

In this study we observed that for the two walking conditions, there are different activation standards, and with the speed increase, the activation increase of all the muscles of the evaluated trunk (IO, MUL, LIC, $\mathrm{EO}$, and AR). We believed that on performing walks at low speed, there is higher temporal variability in exchange of higher dynamic stability [13]. This way, on increasing the speed and instability, the muscles EO, IO, and AR increase the activation producing higher muscular strength and consequently increasing the rigidity of the trunk muscles and, therefore, increasing the stability [27].

MUL muscle showed higher activation with the increase of walking speed and higher cocontraction of the muscles IO/MUL in women with CLP at condition 1 (preferred speed). These data showed that individuals with CLP present 
segmental instability, which results in higher antagonist co-activation, improving the motor control and the trunk stability [28]; however, this strategy results in excessive trunk hardening [29]. These results corroborate the correlation data, which demonstrated that the higher the pain level, the lower the activation of the EO muscle in walking with maximum speed. Thus, the trunk instability increases the pain levels, revealing the LPT susceptibility and its dependence on the global muscles to keep stable [30]. These answers can be caused in individuals with CLP for maintaining the adaptation of the CNS to protect the structures of the spine [30]; however, in the long term, these adaptations overload the spine and cause pain [31].

Regarding the CT, the results showed higher cocontraction for IO/MUL and EO/LIC only at overload moments (condition 2). These are proportional to the increase of co-contraction, demonstrated in the study of Granata and Marras [8], i.e., with the increase of the physical effort, there is also an increase in the co-contraction. These data can be confirmed by the correlation results between the recruitment of the MUL muscle at condition two and the amount of maximum walking speed that demonstrated that the MUL muscle increases its contraction, the higher the physical effort. Even at a situation of higher physical requirement, the CNS is reorganized so that the local muscles increase their activation, maintaining the stability, but even though, remaining with values inferior to the ones reached by LPT $[8,30]$. A previous study analyzed the antagonist activation and cocontraction of the stabilizer muscles after the isometric activation of the IO muscles. I individuals without CLP presented better control of the trunk muscles over individuals with LP [17], corroborating our results.

\section{Conclusion}

The recruitment of the stabilizer muscles does not differ between the teams at different walking speeds; however, there was higher activation of the muscle MUL at CT at condition 2. Regarding the cocontraction, the muscles IO/MUL showed that LPT needed higher activation during condition 1 , while CT increased the activation of the same muscles only at condition 2 , as well as increased the recruitment of the muscles EO/LIC.

\section{References}

1. Watanabe M, Kaneoka K, Okubo Y, Shiina I, Tatsumura M, Miyakawa S. Trunk muscle activity while lifting objects of unexpected weight. Physiotherapy. 2013;99(1):78-83.

2. Deyo RA, Phillips WR. Low back pain: a primary care challenge. Spine. 1996;21(24):2826-32.

3. Salvetti MDG, Pimenta CADM, Braga PE, Corrêa CF. Disability related to chronic low back pain: prevalence and associated factors. Rev Esc Enferm USP. 2012;46(Spec):16-23.

4. Rossi DM, Morcelli MH, Marques NR, Hallal CZ, Gonçalves M, LaRoche DP, et al. Antagonist coactivation of trunk stabilizer muscles during Pilates exercises. J Bodyw Mov Ther. 2014;18(1):34-41.

5. Bergmark A. Stability of the lumbar spine: a study in mechanical engineering. Acta Orthop Scand. 1989;60(Suppl. 230):1-54.

6. Panjabi M. The stabilizing system of the spine: Part I. Function, dysfunction, adaptation, and enhancement. J Spinal Disord. 1992;5(4):383-9.

7. Candotti CT, Carvalho KV, La Torre M, Noll M, Varela M. Ativação e co-contração dos músculos gastrocnêmio e tibial anterior na marcha de mulheres utilizando diferentes alturas de saltos. Rev Bras Cienc Espor. 2012;34(1):27-39.

8. Granata KP, Orishimo KF. Response of trunk muscle coactivation to changes in spinal stability. J Biomech. 2001;34(9):1117-23.

9. McGill SM, Grenier S, Kavcic N, Cholewicki J. Coordination of muscle activity to assure stability of the lumbar spine. J Electromyogr Kinesiol. 2003;13(4):353-9.

10. Lamoth CJC, Daffertshofer A, Meijer OG, Beek PJ. How do persons with chronic low back pain speed up and slow down? Trunk-pelvis coordination and lumbar erector spinae activity during gait. Gait Posture. 2006;23(2):230-9. 
11. Hicks GE, Sions JM, Coyle PC, Pohlig RT. Altered spatiotemporal characteristics of gait in older adults with chronic low back pain. Gait Posture. 2017;55:172-6.

12. Gombatto SP, Brock T, DeLork A, Jones G, Madden E, Rinere C. Lumbar spine kinematics during walking in people with and people without low back pain. Gait Posture. 2015;42(4):539-44

13. Morita AK, Marques NR, Navega MT. Neuromuscular control strategies of the trunk antagonist muscles during the Biering-Sorensen test in individuals with recurrent low back pain and healthy subjects. Motriz Rev Educ Fis. 2016; 22(4):266-71.

14. Dingwell JB, Marin LC. Kinematic variability and local dynamic stability of upper body motions when walking at different speeds. J Biomech. 2006;39(3):444-52.

15. Anders C, Scholle HC, Wagner H, Puta C, Grassme $\mathrm{R}$, Petrovitch A. Trunk muscle co-ordination during gait: Relationship between muscle function and acute low back pain. Pathophysiology. 2005;12(4):243-7.

16. Rossi DM, Morcelli MH, Cardozo AC, Denadai BS, Gonçalves M, Navega MT. Discriminant analysis of neuromuscular variables in chronic low back pain. J Back Musculoskelet Rehabil. 2015;28(2):239-46.

17. Marques NR, LaRoche DP, Hallal CZ, Crozara LF, Morcelli MH, Karuka AH, et al. Association between energy cost of walking, muscle activation, and biomechanical parameters in older female fallers and non-fallers. Clin Biomech. 2013;28(3):330-6.

18. LaRoche DP, Millett ED, Kralian RJ. Low strength is related to diminished ground reaction forces and walking performance in older women. Gait Posture. 2011;33(4):668-72.

19. Hoffman M, Schrader J, Applegate T, Koceja D. Unilateral postural control of the functionally dominant and nondominant extremities of healthy subjects. J Athl Train. 1998;33(4):319-22.
20. Hermens HJ, Freriks B, Merletti R, Stegeman D, Blok J, Rau G, et al. European recommendations for surface electromyography. Enschede: Roessingh; 1999. p. 8-11.

21. Marshall P, Murphy B. The validity and reliability of surface EMG to assess the neuromuscular response of the abdominal muscles to rapid limb movement. J Electromyogr Kinesiol. 2003;13(5):477-89.

22. Burnett AF, Cornelius MW, Dankaerts W, O'Sullivan PB. Spinal kinematics and trunk muscle activity in cyclists: A comparison between healthy controls and non-specific chronic low back pain subjects: a pilot investigation. Man Ther. 2004;9(4):211-9.

23. Marcucci FCI, Cardoso NS, Berteli KS, Garanhani MR, Cardoso JR. Alterações eletromiográficas dos músculos do tronco de pacientes com hemiparesia após acidente vascular encefálico. Arq NeuroPsiquiatr. 2007;65(3b):900-5.

24. Marques NR, Hallal CZ, Gonçalves M. Padrão de coativação dos músculos do tronco durante exercícios com haste oscilatória. Motriz Rev Educ Fis. 2012;18(2):245-52.

25. Winter DA. Biomechanics and motor control of human movement. Hoboken: John Wiley \& Sons; 2009.

26. Peter Reeves N, Narendra KS, Cholewicki J. Spine stability: the six blind men and the elephant. Clin Biomech. 2007;22(3):266-74.

27. Van Dieën JH, Kingma I, Van Der Bug JCE. Evidence for a role of antagonistic cocontraction in controlling trunk stiffness during lifting. J Biomech. 2003;36(12):1829-36.

28. Cholewicki J, Panjabi MM, Khachatryan A. Stabilizing function of trunk flexor-extensor muscles around a neutral spine posture. Spine. 1997;22(19):2207-12.

29. Van Dieën JH, Selen LPJ, Cholewicki J. Trunk muscle activation in low-back pain patients, an analysis of the literature. J Electromyogr Kinesiol. 2003;13(4):333-51. 
30. Hodges PW, Coppieters MW, MacDonald D, Cholewicki J. New insight into motor adaptation to pain revealed by a combination of modelling and empirical approaches. Eur J Pain. 2013;17(8):1138-46.

31. Marras WS, Ferguson SA, Burr D, Davis KG, Gupta P. Spine loading in patients with low back pain during asymmetric lifting exertions. Spine J. 2004;4(1):64-75.
Received in 12/17/2018

Recebido em 17/12/2018

Recibido en $17 / 12 / 2018$

Approved in 11/07/2019

Aprovado em 07/11/2019

Aprobado en 07/11/2019 